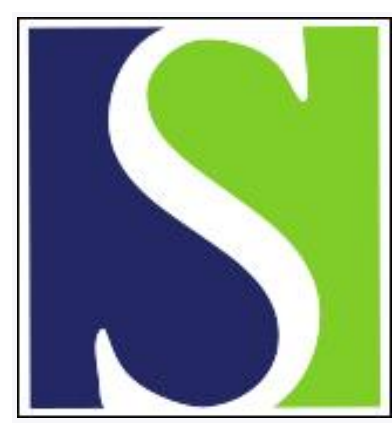

Scand J Work Environ Health 1991;17(6):436-440

https://doi.org/10.5271/sjweh.1683

Issue date: Dec 1991

Determination of exposure to aflatoxins among Danish workers in animal-feed production through the analysis of aflatoxin $B 1$ adducts to serum albumin.

by Autrup JL, Schmidt J, Seremet T, Autrup H

Affiliation: Laboratory of Environmental Carcinogenesis, Danish Cancer Society, Copenhagen.

This article in PubMed: www.ncbi.nlm.nih.gov/pubmed/1788537

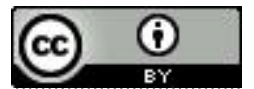




\title{
Determination of exposure to aflatoxins among Danish workers in animal-feed production through the analysis of aflatoxin $B_{1}$ adducts to serum albumin
}

\author{
by Judith L Autrup, PhD, ${ }^{1}$ Jan Schmidt, MD, ${ }^{2}$ Tina Seremet, BSc, ${ }^{1}$ Herman Autrup, $\mathrm{PhD}{ }^{1,3}$

\begin{abstract}
AUTRUP JL, SCHMIDT J, SEREMET T, AUTRUP H. Determination of exposure to aflatoxins among Danish workers in animal-feed production through the analysis of aflatoxin $\mathbf{B}_{1}$ adducts to serum albumin. Scand J Work Environ Health 1992;17:436-40. Aflatoxin $B_{1}$ is suspected as an etiologic factor in the increased risk for primary liver cancer among workers in animal-feed processing plants in Denmark. Aflatoxin bound to serum albumin was therefore measured for feed-processing workers. Blood samples were collected immediately after vacation and after four weeks of work, and aflatoxin was quantified by competitive enzyme-linked immunosorbant assay. Seven of 45 individuals with an estimated exposure of $64 \mathrm{ng}$ aflatoxin $\mathrm{B}_{1} \cdot \mathrm{d}^{-1} \cdot \mathrm{kg}^{-1}$ body weight were positive. Three positive workers had been unloading a cargo with an aflatoxin $B_{1}$ level of $26 \mu \mathrm{g} \cdot \mathrm{kg}^{-1}$ raw material. The exposure level correlated well with the job titles. Dust samples collected at different sites showed considerable variation in the amount of aflatoxin $B_{1}$ (nondetectable to $8 \mu \mathrm{g} \cdot \mathrm{kg}^{-1}$ dust). The exposure to aflatoxin $B_{1}$ may only partially explain the increased risk of liver cancer.
\end{abstract}

Key terms: affinity chromatography, aflatoxin-albumin, biomonitoring, enzyme-linked immunosorbant assay, liver cancer.

Aflatoxin $\mathrm{B}_{1}$, a potent liver carcinogen in experimental animals, is produced by Aspergillus flavus and paraciticus under warm and humid conditions. Aflatoxin $B_{1}$ has been classified as a group 1 carcinogen by the International Agency for Research on Cancer. A positive correlation between the dietary intake of aflatoxin $B_{1}$ and the incidence of liver cancer has been observed in African and Asian countries $(1,2)$. A causative association between exposure to aflatoxins and human cancer has also been established for Dutch workers in an oil mill processing peanuts and linseed; especially the incidence of lung cancer was higher than expected (3). Circumstantial evidence has been reported for an association between the inhalation of aflatoxincontaminated grain dust and lung cancer (4). In a register-based analysis of occupational risk for primary liver cancer in Sweden, a significant excess of cases was observed for workers in grain mills, and it was postulated that potential exposure to aflatoxins may play a role (5). An increased incidence of liver cancer has been reported among Danish male workers in companies processing livestock feed. The exposure of these workers to aflatoxins through the respiratory route was estimated to be $170 \mu \mathrm{g} \cdot \mathrm{d}^{-1}$ according to conservative

' Laboratory of Environmental Carcinogenesis, Danish Cancer Society, Copenhagen, Denmark.

2 Department of Occupational Medicine, Central Hospital, Esbjerg, Denmark.

${ }^{3}$ Institute of Environmental and Occupational Medicine, University of Aarhus, Aarhus, Denmark.

Reprint requests to: Professor $\mathbf{H}$ Autrup, Institute of Environmental and Occupational Medicine, University of Aarhus, Universitetsparken, Building 180, DK-8000 Aarhus C, Denmark estimates (6). Attempts to detect aflatoxin $B_{1}$ or its metabolites in the urine of potentially exposed workers with enzyme-linked immunosorbant assay (ELISA) were unsuccessful due to the presence of aflatoxin-like antigenic material $(7,8)$.

Aflatoxin $\mathrm{B}_{1}$ is metabolized by the mixed function oxidase system to a number of hydroxylated metabolites and to the 8,9-epoxide. The latter is considered the ultimate carcinogenic form that reacts with cellular deoxyribonucleic acid (DNA) and proteins to form covalent adducts. Detection and quantification of these adducts have been suggested as alternative methods to detect human exposure to aflatoxins (9). With the use of ELISA and a monoclonal antibody against aflatoxin $B_{1}$, aflatoxin $B_{1}$ bound to albumin could be detected in blood samples collected in Gambia and Kenya, but not in samples collected in France. The sensitivity of the assay was $5 \mathrm{pg}$ aflatoxin $\mathrm{B}_{1} \cdot \mathrm{mg}^{-1}$ albumin (10). In the present paper we have used a combination of affinity purification of pronase-digested albumin and ELISA to detect aflatoxin adducts to serum albumin from workers potentially exposed to aflatoxin $B_{1}$.

\section{Subjects and methods}

\section{Subjects}

A total of 45 workers at two companies processing livestock feed in Esbjerg, Denmark, 15 at company A and 30 at company B, was included in the study. The workers were either working in the factory and silo (29 workers) or in the harbor unloading ships with raw material for the production (16 workers). They were all men in the age group of 25 to 62 years. None of the 
workers had been working in any other agribusiness for three months prior to the start of this study.

\section{Sample collection}

Blood samples $(5 \mathrm{ml})$ were collected from the workers when they returned to work after at least two weeks of vacation, and then again after four weeks of work.

Dust samples were collected at selected sites in the factories of company A (3 samples) and company B (9 samples). Samples of all shipments of raw material were submitted to analysis for aflatoxin $\mathbf{B}_{1}$ at government-approved laboratories.

\section{Analysis of the blood samples}

Serum was isolated from the blood samples by centrifugation, and albumin was precipitated by the addition of saturated ammonium sulfate, final concentration $50 \%$. After the removal of globulins by centrifugation, albumin was precipitated from the supernatant by acidification with acetic acid (11).

Albumin was redissolved in $500 \mu \mathrm{l}$ of $0.1 \mathrm{M}$ sodium phosphate buffer, $\mathrm{pH} 7.4$, and digested with pronase (Fluka, Buchs, Switzerland, 25 units per $5 \mathrm{mg}$ of albumin) for $18 \mathrm{~h}$ at $37^{\circ} \mathrm{C}$. The concentration of albumin was determined by the Biuret reagent (Sigma, St Louis, Missouri, United States, kit 540-2) assay. The digest was applied to a prewet C18 Seppak column (Waters, Milford, Massachusetts, United States). The column was washed with $5 \mathrm{ml}$ of $5 \%$ methanol to remove small peptides and amino acids, before the aflatoxin $\mathrm{B}_{1}$-containing fraction was eluted in $80 \%$ methanol $(5 \mathrm{ml})$. This fraction was evaporated to $0.5 \mathrm{ml}$ and was diluted to make $10 \%$ methanol $(1 \mathrm{ml})$. The eluate was applied to an Aflatest ${ }^{\circledR}$ affinity column (Vicam, Sommerville, Massachusetts, United States) (10), and the aflatoxin $B_{1}$-containing fraction was eluted with $1.5 \mathrm{ml}$ of methanol in phosphate buffer $0.1 \mathrm{M}, \mathrm{pH} 7.4$ (1:1) after the column was rinsed with phosphate buffered saline (PBS) $(5 \mathrm{ml})$. With the use of albumin isolated from rats treated with radiolabeled aflatoxin $B_{1}$, the recovery was estimated to be $80 \%$.

\section{Enzyme-linked immunosorbant assay}

Polystyrene microtiter plates (Teknunc, Roskilde, Denmark) were coated with aflatoxin $B_{1}$-bovine serum albumin (Sigma) or bovine serum albumin (BSA) as previously described (8). On each plate $100 \mu \mathrm{l}$ of the eluates and five aflatoxin $(25,2.5,0.25,0.025$, and $0.0 \mathrm{ng} \cdot \mathrm{ml}^{-1}$ ) standards were added immediately before $100 \mu \mathrm{l}$ of a solution of monoclonal antibody AW-1 (12) (diluted 1:1000 with PBS) was applied to compete for binding. The plates were incubated overnight at $4^{\circ} \mathrm{C}$, then washed with $0.05 \%$ Tween 20 (polyoxyethylene sorbitan monolaurate) in PBS before incubation with the secondary antibody, goat antimouse immunoglobulin $\mathrm{G}$ conjugated with alkaline phosphatase
(Dakopatts, Glostrup, Denmark) (diluted 1:1000 in $1 \% \mathrm{BSA}$ in PBS), for $2 \mathrm{~h}$ at room temperature. Following washing with $0.05 \%$ Tween 20 in PBS and $0.1 \mathrm{M}$ diethylamine buffer ( $\mathrm{pH}$ 9), $100 \mu \mathrm{l}$ of 4-nitrophenyl phosphate substrate (Sigma $(1 \mathrm{mg} / \mathrm{ml})$ was added to each well, and the plates were incubated for $2 \mathrm{~h}$ at room temperature. The absorption was read at $405 \mathrm{~nm}$. The intrasample variation was less than $2 \%$.

\section{Analysis of the dust samples}

Aflatoxin was isolated from the dust samples with a modification of the standard procedure provided by the manufacturers of Aflatest ${ }^{\circledR}$ affinity columns.

Dust samples $(0.9 \mathrm{mg})$ were suspended in $5 \mathrm{ml}$ of $80 \%$ methanol, $0.1 \mathrm{mg}$ of sodium chloride was added, and the samples were extracted by shaking for $30 \mathrm{~min}$ in the dark. The extracts were centrifuged for $20 \mathrm{~min}$, and the supernatants were collected. This procedure was repeated, and the supernatants were pooled. Three milliliters of the extract was adjusted to $10 \%$ methanol, and $10 \mathrm{ml}$ of this solution was loaded onto the Aflatest ${ }^{\circledR}$ affinity column. After being washed with distilled water the aflatoxins were eluted with $100 \%$ methanol. The quantities of aflatoxins were determined in ELISA assays as has already been described.

\section{Results}

The sensitivity of the analysis using Seppak prepurification and affinity chromatography prior to quantitative analysis with ELISA was $5 \mathrm{pg}$ aflatoxin $\mathrm{B}_{1} \cdot \mathrm{mg}^{-1}$ albumin, corresponding to $30 \%$ inhibition. It was assumed that, with the use of the AW-1 antibody, the antigenicity of aflatoxin $B_{1}$ adducts to amino acids was similar to that of aflatoxin $\mathbf{B}_{2 \mathrm{a}}$, as epitope mapping indicated that modification at the 7,8 position only had minor influence on antibody recognition (8). In an attempt to increase the sensitivity of the assay, different concentrations of unmodified BSA were added. Albumin in the amount of $5 \mathrm{mg} /$ incubation did not influence the quantification.

Blood samples were collected from workers with different levels of suspected exposure to material contaminated with aflatoxin $B_{1}$ according to job descriptions (table 1). Workers exposed to grain dust for more than $50 \%$ of their workhours were classified as highly exposed, and those exposed for less than $25 \%$ of the workday were considered to have low exposure. Two of the 45 blood samples collected from the workers upon return from vacation indicated recent exposure to aflatoxin $B_{1}\left(50\right.$ and $54 \mathrm{pg}$ aflatoxin $B_{1}$. $\mathrm{mg}^{-1}$ albumin), while all of the other samples were below the detection level of $5 \mathrm{pg}$ alfatoxin $\mathrm{B}_{1} \cdot \mathrm{mg}^{-1}$ albumin. After four weeks of work 7 of 45 workers had detectable levels of aflatoxin $\mathbf{B}_{1}$, a finding suggesting occupational exposure to aflatoxin $\mathrm{B}_{1}$ (table 2). The mean level of the positive samples was ex- 
pressed as $64 \mathrm{ng} \cdot \mathrm{d}^{-1} \cdot \mathrm{kg}^{-1}$ body weight on the assumption that the exposure was equally distributed over the four weeks of work and the average body weight was $70 \mathrm{~kg}$. All of the workers with exposure to aflatoxin $\mathrm{B}_{1}$ were employed by company $\mathrm{B}$, but with different job descriptions and different types of prescribed personal protection.

In the three-month period prior to the second blood sample, the level of aflatoxin $B_{1}$ in the raw material arriving in company $\mathrm{A}$ was less than $5 \mu \mathrm{g} \cdot \mathrm{kg}^{-1}$. One shipment of peanut meal/coconut pills to company B had an aflatoxin content greater than $5 \mu \mathrm{g} \cdot \mathrm{kg}^{-1}$, and another had an aflatoxin $B_{1}$ level of $26 \mu \mathrm{g} \cdot \mathrm{kg}^{-1}$. Three out of the five workers with the highest antigenicity helped to unload the latter cargo (table 3 ). One of the workers with a detectable level of aflatoxin adducts to albumin but with suspected low exposure based upon his job description had a supervisory function at the grill where batches of raw material from different silos were dumped for use in production. Dust samples collected at this site had an aflatoxin $\mathbf{B}_{1}$ content of $8 \mu \mathrm{g} \cdot \mathrm{kg}^{-1}$ dust. The aflatoxin $B_{1}$ content at the other sites of collection was generally low.

Table 1. Participants according to worksite and potential aflatoxin exposure. ( $\mathrm{L} / \mathrm{M}=$ low/medium, $\mathrm{H}=$ high)

\begin{tabular}{lcc}
\hline & $\begin{array}{c}\text { Potential } \\
\text { exposure }\end{array}$ & $\begin{array}{c}\text { Number of } \\
\text { participants }\end{array}$ \\
\cline { 2 - 3 } Company A & & \\
Factory/silo & LM & 9 \\
$\begin{array}{l}\text { Dock } \\
\text { Company B }\end{array}$ & $\mathrm{H}$ & 4 \\
Factory/silo & & \\
Factory & LM & 8 \\
Dock group 1 & LM & 12 \\
Dock group 2 & H & 5 \\
\hline
\end{tabular}

\section{Discussion}

Human exposure to airborne or particle-borne chemical compounds can be determined either by ambient air monitoring or by the detection of the compounds or their metabolites in body fluids. However, these measurements do not give any information on the potential biological effect of the exposure. Quantification of a carcinogenic adduct to protein or DNA is an indirect measure of the amount of the active metabolite formed in the organism (13). A linear relationship between hepatic aflatoxin $B_{1}$ adducts to DNA and the risk for developing liver cancer among rodents has been reported. In the present study the binding of aflatoxin $B_{1}$ to serum albumin has been used as the monitor. One of the advantages of using serum albumin rather than, for example, lymphocyte DNA is that the measured level represents the accumulated dose during the half-time of the serum albumin, as no repair pathways are known, whereas the half-time of aflatoxin adducts to DNA in experimental animals is less than $24 \mathrm{~h}$. A good correlation between the binding of aflatoxin $\mathrm{B}_{1}$ to serum albumin and liver DNA has been reported for experimental animals (14). This finding suggests that binding to serum albumin is a good monitor for the binding to target cell DNA even at low doses of aflatoxin $B_{1}$. It has been estimated that approximately $5 \%$ of the administered dose binds to albumin (10). The major aflatoxin $B_{1}$ adduct to albumin has been identified as being formed between the active form of aflatoxin $B_{1}$ and lysine (15). With the use of affinity purification of albumin hydrolysate of aflatoxin $\mathbf{B}_{1}$ in combination with radioimmunoassay, a correlation was observed between the intake of aflatoxin, as measured by food analysis, and aflatoxin adduct to lysine in a Chinese population (16). However, this assay gave an overestimate in comparison with affinity chromatography combined with high-pressure liquid chromatography with fluorescence detection (17). Aflatoxin $B_{1}$

Table 2. Individuals exposed to aflatoxin $B_{1}$ - exposure determined by amount of aflatoxin $B_{1}$ adducts bound to serum albumin. ( $L=$ less than $25 \%$ of workhours, $S=$ more than $50 \%$ of workhours, ND = not detectable - less than $5 \mathrm{pg} / \mathrm{mg}$ )

\begin{tabular}{|c|c|c|c|}
\hline \multirow{2}{*}{ Work area } & \multirow{2}{*}{$\begin{array}{l}\text { Worktime in } \\
\text { contaminated } \\
\text { areas }\end{array}$} & \multicolumn{2}{|c|}{$\begin{array}{c}\text { Aflatoxin } B_{1} \text { adducts } \\
\text { (pg aflatoxin } B_{1} \cdot \mathrm{mg}^{-1} \text { albumin) }\end{array}$} \\
\hline & & $\begin{array}{l}\text { First blood } \\
\text { sample }\end{array}$ & $\begin{array}{l}\text { Second blood } \\
\text { sample }\end{array}$ \\
\hline \multicolumn{4}{|c|}{ Company B, silo } \\
\hline $\begin{array}{l}\text { Worker } 1 \\
\text { Worker } 2\end{array}$ & $\stackrel{L}{S / L}$ & $\begin{array}{l}\text { ND } \\
\text { ND }\end{array}$ & $\begin{array}{l}58 \\
64\end{array}$ \\
\hline \multicolumn{4}{|c|}{ Company B, factory } \\
\hline $\begin{array}{l}\text { Worker } 3 \\
\text { Worker } 4 \\
\text { Worker } 5\end{array}$ & $\begin{array}{l}S \\
L \\
S\end{array}$ & $\begin{array}{l}54 \\
50 \\
\text { ND }\end{array}$ & $\begin{array}{l}44 \\
\text { ND } \\
50\end{array}$ \\
\hline \multicolumn{4}{|c|}{ Company B, dock, team 2} \\
\hline $\begin{array}{l}\text { Worker } 6 \\
\text { Worker } 7 \\
\text { Worker } 8 \\
\text { Worker } 9\end{array}$ & $\begin{array}{l}S \\
S \\
S \\
S\end{array}$ & $\begin{array}{l}\text { ND } \\
\text { ND } \\
\text { ND } \\
\text { ND }\end{array}$ & $\begin{array}{r}88 \\
100 \\
50 \\
\text { ND }\end{array}$ \\
\hline
\end{tabular}


adducts to lysine have not been detected in people living in Western Europe.

In this paper, we report the presence of aflatoxin $B_{1}$ adducts to lysine in the serum albumin of some workers who have been unloading aflatoxin $\mathrm{B}_{1}$-contaminated raw material for animal-feed production. Aflatoxins are frequently found in respirable grain dusts that are common in grain silos and are produced by the handling of the raw material for animal feed pellets $(3,18)$. Two of the workers had a detectable level of aflatoxin $B_{1}$ adducts to serum albumin upon return from vacation, but the adducts disappeared or their concentration dropped slightly in the subsequent four weeks. The source of this aflatoxin $B_{1}$ exposure is unknown, as the workers were neither involved in any other type of agribusiness during vacation nor had their own farms. It should be noted that one of these workers had only had two weeks of vacation and that the detectable level of aflatoxin $\mathrm{B}_{1}$-albumin could have been caused by exposure prior to vacation. The half-time of albumin is more than three weeks. Only three out of five workers unloading the heavy contaminated cargos had a detectable level of exposure, although the same type of personal protection was in use. However, these workers implemented different job functions. Another explanation for the different adduct levels with the same exposure could be an interindividual difference in the metabolism of aflatoxin $\mathbf{B}_{1}$ to biologically active metabolites or detoxified products (19). One of the workers in the silo at factory B had a fairly high level of aflatoxin $B_{1}$ adducts to albumin although his estimated exposure to dust particles was low, less than $25 \%$ of the workhours. He had a supervisory function controlling the ramp for unloading the raw material and grain for transport to the factory. Dust samples collected at this site showed a fairly high level of aflatoxin $B_{1}\left(8 \mu \mathrm{g} \cdot \mathrm{kg}^{-1}\right)$ compared with the $1 \mu \mathrm{g} \cdot \mathrm{kg}^{-1}$ or nondetectable level at the other collection sites in the silo or factory. As such, there appears to be a good association between the level of aflatoxin $B_{1}$ adducts to albumin and exposure, as measured by the analysis of dust or raw material. An excess number of liver cancer cases has been reported in this group of workers (6), and attempts were made to explain the number of cases on the basis of the level of exposure to aflatoxin $B_{1}$. The mean level of exposure, only including the individuals with detectable levels, was $64 \mathrm{ng}$ aflatoxin $\mathrm{B}_{1} \cdot \mathrm{kg}^{-1} \cdot \mathrm{d}^{-1}$ on the assumption that $5 \%$ of the dose binds to albumin and that the exposure was equally distributed over the 30 workdays between the two blood samples. This estimated level was slightly higher than the level of exposure in an area with an intermediate liver cancer rate; in this area the exposure had been estimated to be 16.5 $\mathrm{ng} \cdot \mathrm{kg}^{-1}(20)$.

On the assumption that the measured exposure is representative for the aflatoxin $B_{1}$ exposure of the workers at the animal-feed manufacturing companies in Denmark over an extended period of many years,
Table 3. Control measurements of aflatoxin $B_{1}$ in raw material unloaded during the four weeks prior to the second blood sample.

\begin{tabular}{cccc}
\hline Company & $\begin{array}{c}\text { Amount of } \\
\text { raw material } \\
(\mathrm{t})\end{array}$ & $\begin{array}{c}\text { Amount of } \\
\text { aflatoxin } \mathrm{B}_{1}^{\mathrm{a}} \\
\left(\mu \mathrm{g} \cdot \mathrm{kg}^{-1}\right)\end{array}$ & $\begin{array}{c}\text { Number of } \\
\text { workers } \\
(\text { positive/ } \\
\text { exposed })\end{array}$ \\
\hline $\begin{array}{c}\text { Company A } \\
\text { Team 1 }\end{array}$ & 4.612 & $<5$ & -14 \\
Company B & & & \\
Team 1 & 8.850 & $<5$ & -15 \\
Team 2 & 2.100 & $8-9$ & -15 \\
\hline
\end{tabular}

a This analysis is required by to the Department of Agriculture, and the results have been provided by the companies.

85 liver cancer cases per million exposed individuals per year would be expected according to the linear regression data from correlation studies on aflatoxin $\mathrm{B}_{1}$ exposure and liver cancer incidences (21). Among the 2000 members of the trade unions representing the workers, only 1.7 new cases of liver cancer should be expected from the monitoring data in comparison with the observed value of 3 cases (6). Exposure to carcinogens normally takes place $10-30$ years prior to the diagnosis of cancer. The quality of the raw material, the number of cargoes contaminated with aflatoxins, and the work environment have changed considerably in the last 10 years so that the measurements made today are not representative of the period in which the liver cancer patients were exposed. As only a few of the trade union members are currently exposed, a lower number than 1.7 cases $/ 10$ years is to be expected.

In addition to its carcinogenic effect, aflatoxin $B_{1}$ has been suggested to influence the immune system (22). The efforts made by the companies to reduce the level of aflatoxin $B_{1}$ in the raw material, as well as encapsuling the work process, will remove some of the health hazards associated with work in the animal-feed manufacturing companies.

\section{References}

1. Munoz N, Bosch FX. Epidemiology of hepatocellular carcinoma. In: Okuda K, Ishak KG, ed. Neoplasma of the liver. Tokyo: Springer, 1987:3-19.

2. Autrup H, Seremet T, Wakhisi J, Wasunna A. Aflatoxin exposure measured by urinary excretion of aflatoxin B1-guanine adduct and hepatitis B virus infection in areas with different liver cancer incidence in Kenya. Cancer Res 1987;47:3430-6.

3. Hayes RB, Van Nieuwenhuize JP, Raatgever JW, Kate FJW. Aflatoxin exposures in the industrial setting: an epidemiological study of mortality. Food Chem Toxicol 1984;22:39-44.

4. Dvorackova I, Stora C, Ayraud N. Evidence for aflatoxin $\mathrm{B} 1$ in two cases of lung cancer in man. $\mathrm{J}$ Cancer Res Clin Oncol 1981;100:221-4.

5. McLaughlin JK, Malker HSR, Malker BK. Registrybased analysis of occupational risk for primary liver cancer in Sweden. Cancer Res 1987;47:287-93.

6. Olsen JH, Dragsted L, Autrup H. Cancer risk and oc- 
cupational exposure to aflatoxins in Denmark. Br J Cancer 1988;58:392-6.

7. Dragsted LO, Larsen AI, Bull I, Autrup H. Aflatoxinudskillelse hos erhverseksponerede havnearbejdere. Ugskr Laeger 1985;147:4148-50.

8. Dragsted LO, Bull I, Autrup H. Substances with affinity to a monoclonal aflatoxin B1 antibody in Danish urine samples. Food Chem Toxicol 1988;26:233-42.

9. Autrup JL, Autrup H. Human exposure to aflatoxins - biological monitoring. In: Bhatnager, ed. Handbook of applied mycology; vol 5 (Mycotoxins in ecological systems). New York, NY: Marcel Dekker, in press

10. Wild CP, Jiang Y-Z, Sabbioni G, Chapot B, Montesano R. Evaluation of methods for quantification of aflatoxin-albumin adducts and their application to human exposure assessment. Cancer Res 1990;50:245-51.

11. Shearson D, Sabro P, Sigsgaard T, Johansen F, Autrup H. Biological monitoring of foundry workers exposed to polycyclic aromatic hydrocarbons. $\mathrm{Br} \mathrm{J}$ Ind Med 1990; 47:448-453.

12. Sun $\mathrm{T}, \mathrm{Wu} \mathrm{Y}, \mathrm{Wu} \mathrm{S}$. Monoclonal antibody against aflatoxin B1, and its potential applications. Chin J Oncol 1983;5:401-5.

13. Autrup H. Human exposure to genotoxic carcinogens: methods and their limitations. $\mathbf{J}$ Cancer Res Clin Oncol 1991;117:6-12.

14. Bechtel DH. Molecular dosimetry of hepatic aflatoxin B1-DNA adducts: linear correlation with hepatic cancer risk. Regul Toxicol Pharmacol 1989;10:74-81.

15. Sabbioni G. Chemical and physical properties of the major serum albumin adducts of aflatoxin $B 1$ and their applications for the quantitation in biological samples. Chem Biol Interact 1990;75:1-15.

16. Gan LS, Skipper PL, Peng X, et al. Serum albumin adducts in the molecular epidemiology of aflatoxin carcinogenesis: correlation of aflatoxin B1 intake and urinary excretion of aflatoxin M1. Carcinogenesis 1988; 9:1323-5.

17. Sabbioni G, Ambs S, Wogan GN, Groopman JD. The aflatoxin-lysine adduct quantified by high-performance liquid chromatography from human serum albumin samples. Carcinogenesis 1990;11:2063-6.

18. Sorensen WG, Jones W, Simpson J, Davidson JI. Aflatoxin in respirable airborne peanut dust. J Toxicol Environ Health 1984;14:525-33.

19. Forrester LM, Neal GE, Judah DJ, Glancey MJ, Wolf $\mathrm{CR}$. Evidence for the involvement of multiple forms of cytochrome P-450 in aflatoxin B1 metabolism in human liver. Proc Natl Acad Sci USA 1990;87:8306-10.

20. Van-Rensburg SJ, van-Schalkwyk GC, van-Schalkwyk DJ. Primary liver cancer and aflatoxin intake in Transkei. J Environ Pathol Toxicol Oncol 1990;10:11-6.

21. Report from a working group: health evaluation of aflatoxins in foodstuffs. Copenhagen: Danish Institute of Toxicology, National Food Agency, 1989:1-50.

22. Pestka JJ, Bondy GS. Alteration of immune function following dietary mycotoxin exposure. Can J Physiol Pharmacol 1990;68:1009-16.

Received for publication: 15 April 1991 